lished runoff data for the Kangerluarsunnguaq basin were provided by the Section for Hydro-technical Investigations, Greenland Technical Organization.

\section{References}

Braithwaite, R. J. 1982: A simple model of runoff from ungauged basins in West Greenland. Rapp. Grønlands geol. Unders. 111, 26 pp.

Braithwaite, R. J. 1987: The last full summer of glacier-climate investigations at Qamanârssûp sermia, West Greenland. Rapp. Grønlands geol. Unders. 135, 95-98.

Braithwate, R. J. \& Olesen, O. B. 1988: Effect of glaciers on annual run-off, Johan Dahl Land, South Greenland. J. Glaciol. 34, 200-207.

Braithwaite, R. J. \& Olesen, O. B. in press 1: Winter accumulation reduces summer ablation on Nordbogletscher, South Greenland. Z. Gletscherk. Glazialgeol. 24.
Braithwaite, R. J. \& Olesen, O. B. in press 2: Detection of ablation signal by inter-stake correlation of annual ablation data, Qamanârssûp sermia, West Greenland. J. Glaciol.

GTO 1986: Generelle hydrologiske bassin informationer: bynære bassiner 1986, supplement 1, 113 pp. Copenhagen: Grønlands Tekniske Organisation.

Thomsen, H. H. \& Braithwaite R. J. 1987: Use of remote sensing data in modelling runoff from the Greenland ice sheet. Ann. Glaciol. 9, 215-217.

Weidick, A. \& Thomsen, H. H. 1983: Lokalgletschere og Indlandsisens rand $\mathrm{i}$ forbindelse med udnyttelse af vandkraft i bynære bassiner. Gronlands geol. Unders. Gletscher-hydrol. Meddr 83/2, 129 pp.

R. J. B. \& H. H.T., Grønlands Geologiske Undersøgelse, Øster Voldgade 10, DK-1350 København K, Danmark.

\title{
Evaluation of the niobium-tantalum potential of the Motzfeldt Centre, South Greenland
}

\author{
Bjørn Thomassen
}

The Motzfeldt 87 Project, initiated in June 1987, was completed in May 1988 with the publication of the final report (Thomassen, 1988). The project consisted of a detailed investigation of selected parts of the niobiumtantalum-uranium-bearing pyrochlore mineralisation at Motzfeldt Sø, South Greenland (fig. 1). The purpose of the project was to gain a general impression of the metal distribution in the mineralised zones and to delineate areas with high metal contents. The project was carried out as a joint programme between GGU and Nunaoil A/S under the supervision of GGU, and was mainly funded by the Mineral Resources Administration for Greenland.

The field work in July and August 1987 involved twenty persons and comprised an airborne gamma-spectrometric survey, a major chip sampling programme and minor reconnaissance (Thomassen \& Tukiainen, 1987; Thomassen et al., 1988). The subsequent laboratory work covered lithological logging and chemical analysis of chip samples, statistical treatment of analytical results, and preparation of geophysical and geochemical anomaly maps (Thomassen, 1987, 1988).

During the project the following contractors were employed: Greenlandair Charter A/S (helicopter support); Global Earth Sciences Ltd., England (airborne gamma-spectrometric survey); Garaventa AG., Swit- zerland (mountaineering team); Bondar-Clegg \& Co. Ltd. and Chemex Labs Ltd., both Canada (chemical analyses); and IMSOR Image Processing Group, Technical University of Denmark (statistical analysis).

\section{Geology and mineralisation}

The $c .300 \mathrm{~km}^{2}$ Motzfeldt Centre belongs to the Proterozoic alkaline Gardar province in South Greenland. The centre was mapped geologically in the period 19611970 by GGU geologists (Emeleus \& Harry, 1970), and in the period 1979-1985 GGU expeditions, partly funded by the European Economic Community, discovered and investigated a widespread pyrochlore mineralisation (Armour-Brown et al., 1980; Armour-Brown et al., 1983; Tukiainen et al., 1984; Tukiainen, 1986, 1988).

The Motzfeldt Centre consists of syenites and nepheline syenites which were intruded into the Proterozoic Julianehåb granite and Gardar supracrustal rocks some $1310 \mathrm{Ma}$ ago. The main igneous phase is composed of a number of concentric, steep-sided, outward dipping units of peralkaline rocks. In the outermost of these units, the Motzfeldt Sø Formation, large quantities of roofing sandstones and volcanics have been incorporated. The volcanics are preserved as rafts, whereas the sandstones have been assimilated and have created an 


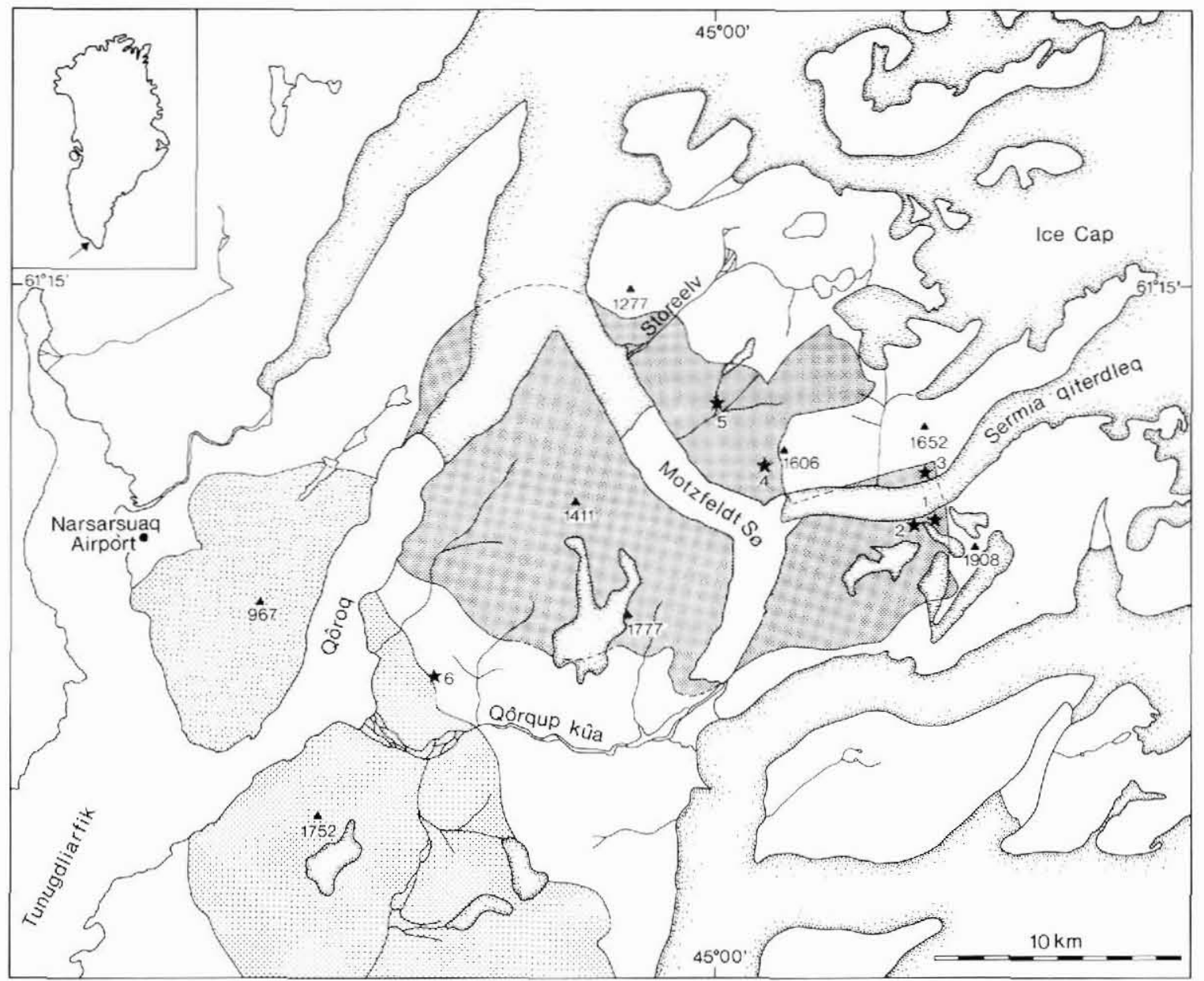

Fig. 1. Map of the Motzfeldt $\mathrm{S} \wp$ area. The Motzfeldt Centre is dark grey, other Gardar intrusions are light grey. The investigated localities are indicated with stars.

outer zone of the formation with a silica saturated composition. The formation underwent extreme differentation resulting in the formation of a peralkaline residuum rich in volatile and incompatible elements. This residuum gave rise to a complex of late peralkaline sheets of microsyenite and pegmatite, and to hydrothermal alteration with associated mineralisation.

$\mathrm{Nb}-\mathrm{Ta}-\mathrm{U}-\mathrm{Th}-\mathrm{Zr}$-Ce-La mineralisation is hosted in altered syenite and peralkaline microsyenite of the Motzfeldt $\mathrm{S} \emptyset$ Formation. The metals occur mainly in pyrochlore (Nb, Ta, U, REE), thorite (Th), zircon ( $\mathrm{Zr}$ ) and bastnaesite (REE, Th). Minor sulphide mineralisation is associated with some fault zones.

The pyrochlore contains between $1.3 \%$ and $8.3 \% \mathrm{Ta}$, and its $\mathrm{Nb} / \mathrm{Ta}$ ratio varies from 8 to more than 50 . In general, tantalum contents are higher in pyrochlore from altered syenite than in pyrochlore from peralkaline microsyenite. The mineral also shows a marked compositional variation depending on its relative depth in the Motzfeldt Sø Formation. At the deeper levels it is enriched in tantalum and calcium, whereas at the higher levels it is enriched in niobium, uranium and light rare earth elements (Tukiainen, 1986).

\section{Airborne gamma-spectrometric survey}

An airborne radiometric survey of the whole Motzfeldt $S ø$ area in 1982 (Tukiainen et al., 1984) and subsequent research (Tukiainen, 1986) showed that pyrochlore mineralisation is efficiently pin-pointed by gamma-spectrometry. As the pyrochlore contains uranium, but only little thorium, the mineralised zones are registered as areas with high count rates in the uranium channel and high U/Th ratios. The purpose of the 1987 survey was thus to outline anomalies in detail and to facilitate the extrapolation of geochemical results beyond the sampled areas.

Six prospective areas defined during previous work 


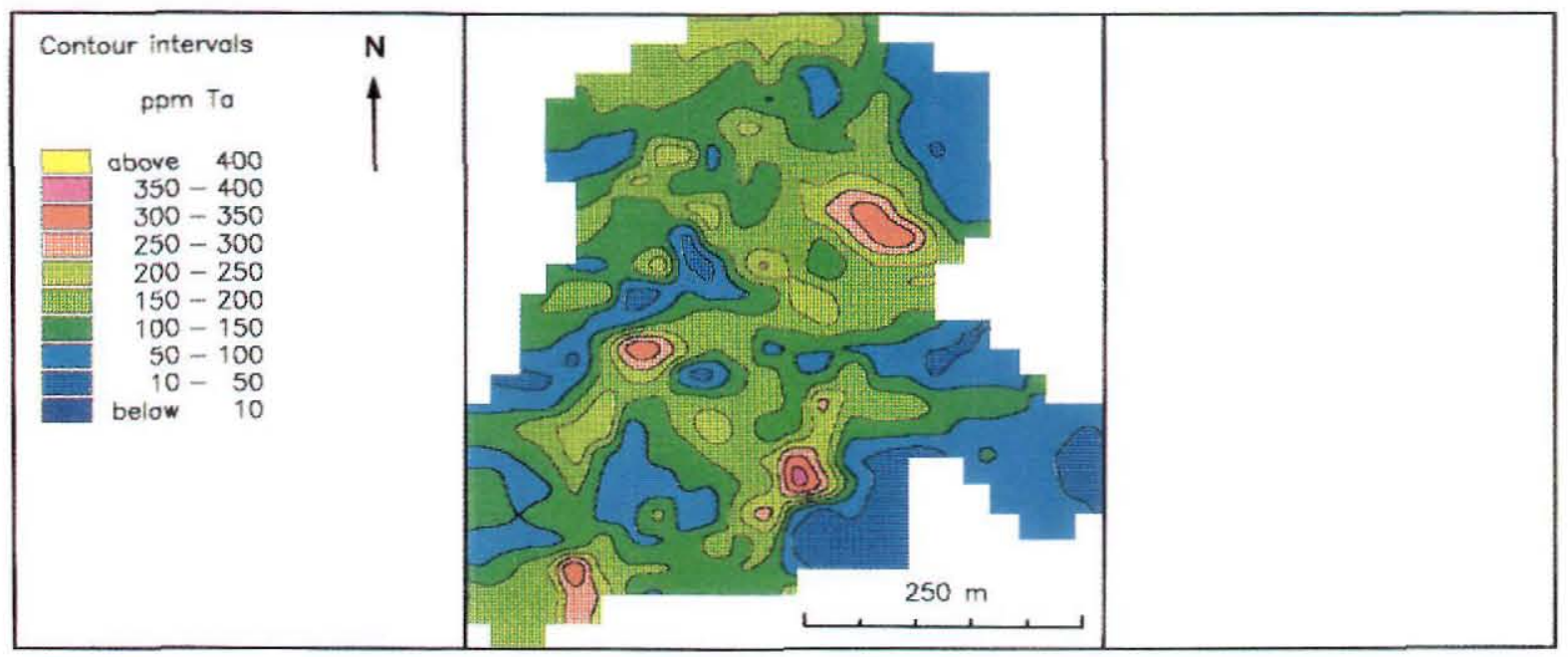

a

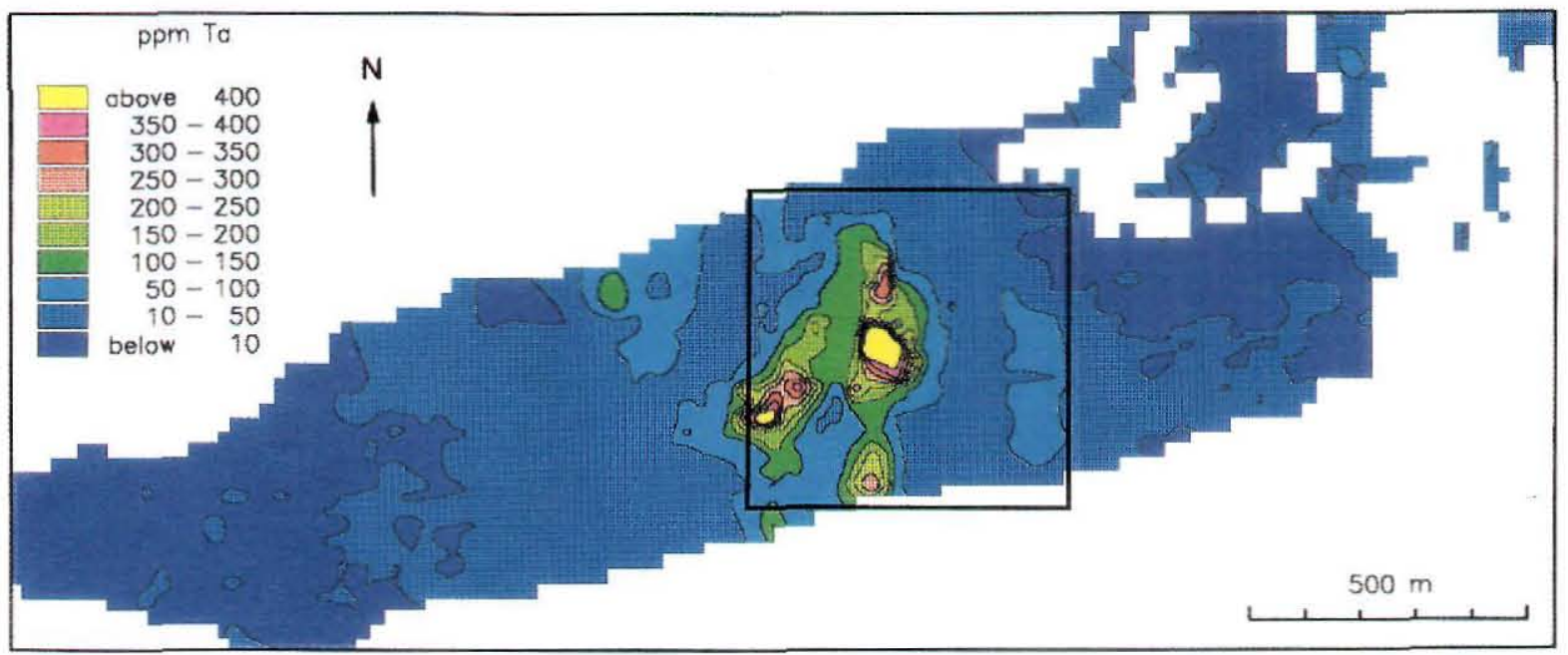

$\mathrm{b}$

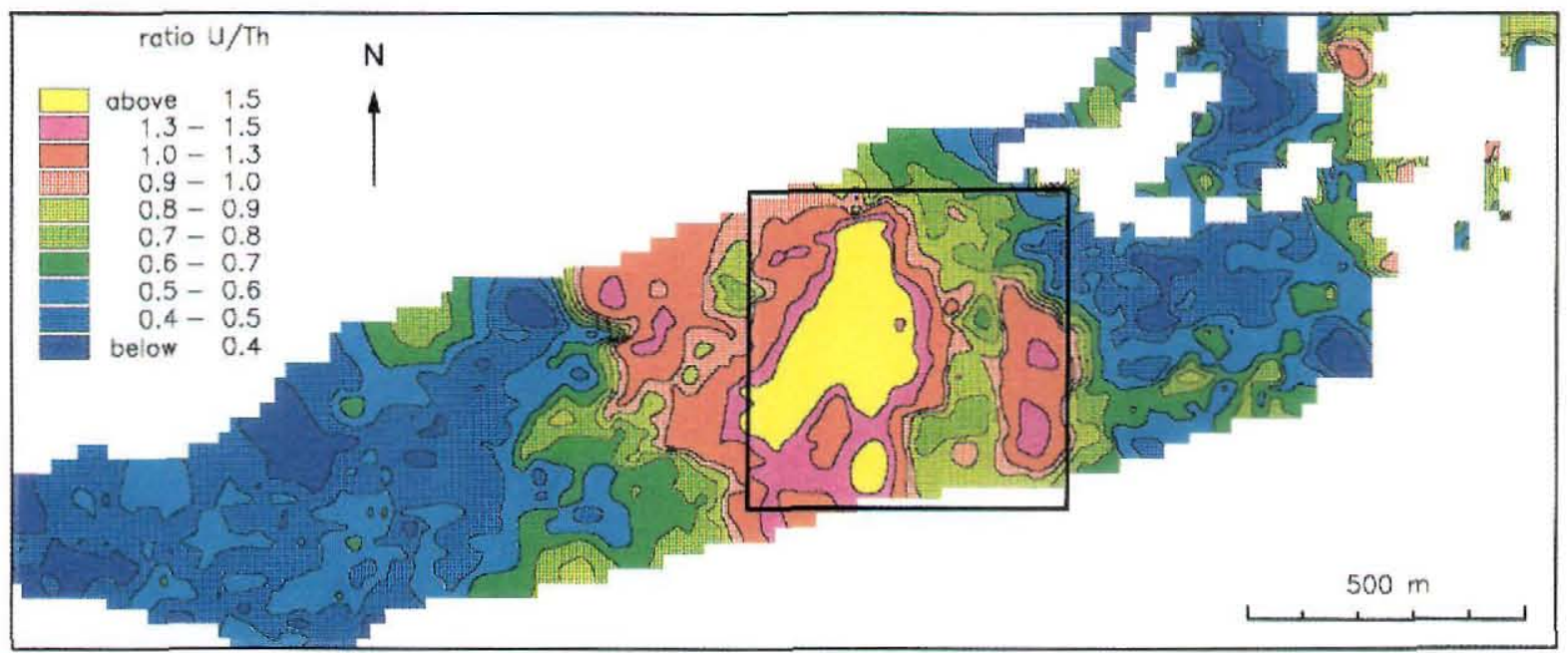

C

Fig. 2. Examples of contoured anomaly maps from locality 3 (cf. topography and sample points at fig. 3). (a) Interpolated map of tantalum. (b) Extrapolated map of tantalum, framed area corresponds to (a). (c) Map of airborne radiometric U/Th ratios, framed area corresponds to (a). 
Fig. 3. Map of locality 3. Dots indicate chip sample points.

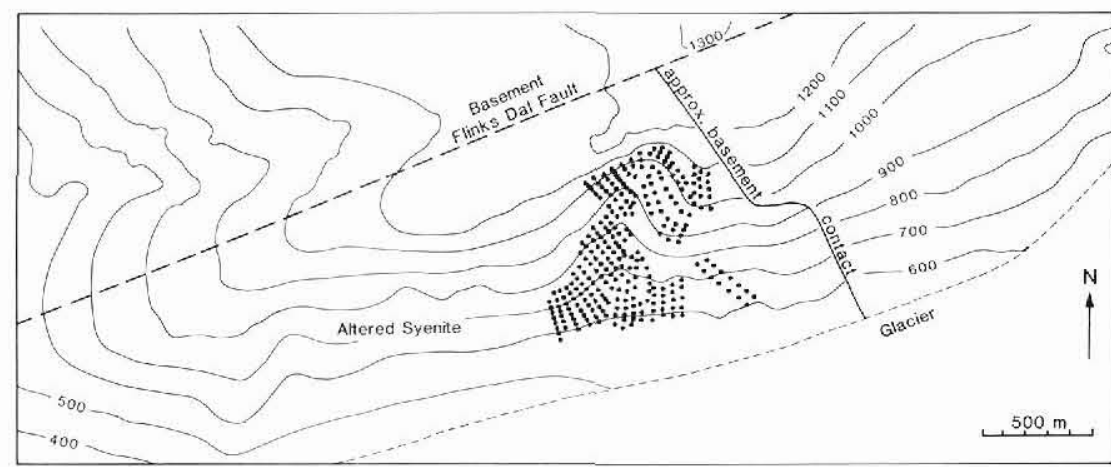

were flown with a gamma-spectrometer mounted in a helicopter in the first two weeks of the field season (fig. 1). The airborne system recorded and stripped values for uranium, thorium, potassium and total gamma radiation. The survey was mainly carried out by contour flying with a contour spacing of $30 \mathrm{~m}$ and a ground clearance of $30 \mathrm{~m}$. A total of 454 line $\mathrm{km}$ were flown, and 63443 measurements with an average point separation of $c .7 \mathrm{~m}$ were recorded over an area of $c .18$ $\mathrm{km}^{2}$.

Preliminary results as anomaly maps of raw data were available immediately after the completion of the survey and were used to guide the chip sampling programme. Final results based on corrected data were presented as stacked gamma-spectrometric profiles (Thomassen, 1987) and as contoured anomaly maps of cps uranium, thorium and U/Th ratios (Thomassen, 1988). The latter were prepared by minimum curvature interpolation techniques (Briggs, 1974). An example is shown in fig. $2 \mathrm{c}$.

\section{Chip sampling programme}

As the outcropping pyrochlore mineralisation is mainly situated on steep mountain cliffs $700-1200 \mathrm{~m}$ high, previous assessments of metal contents were based on evidence from scree boulders and from traverses along the foot and top of the cliffs. The main purpose of the present project was to gain reliable information on the metal contents in the outcrops with the highest pyrochlore contents. To fulfil this purpose, the most promising of the gamma anomalies outlined by the airborne survey were systematically sampled at five localities (fig. 1). Locality 6 was not visited.

Field work. The sampling was carried out by six professional mountaineers under supervision of the project geologist. The mineralised localities were sampled on 25 $\times 25 \mathrm{~m}$ or $50 \times 50 \mathrm{~m}$ grids, with one set of the grid lines perpendicular to the contours (fig. 3). At each sample site a chip sample was collected over an area of $4 \mathrm{~m}^{2}$, and thereafter a scintillometer reading was recorded. A total of 928 chip samples with an average weight of 1.8 $\mathrm{kg}$ were collected over approximately $1.8 \mathrm{~km}^{2}$ of slope areas.

Lithological logging. The logging of the chip samples showed the following frequency of rock types: altered syenite $(55 \%)$, peralkaline microsyenite $(29 \%)$, trachyte $(5 \%)$, basalt $(4 \%)$, aplite $(4 \%)$ and pegmatite $(3 \%)$. It also appeared that locality 1 is mainly underlain by peralkaline microsyenite, whereas localities 2 to 5 are dominated by altered syenite.

Chemical analysis. The chip samples were assayed for $\mathrm{Nb}, \mathrm{Ta}, \mathrm{U}$ and $\mathrm{Th}$, and analysed for Be, Ce, La, Li, Mo, $\mathrm{Sn}, \mathrm{Y}$ and $\mathrm{Zr}$. The analytical methods were instrumental neutron activation (Ce, La, Ta, U, Th), X-ray fluorescence $(\mathrm{Nb}, \mathrm{Sn}, \mathrm{Zr}, \mathrm{Y})$ and atomic absorption (Be, Li, Mo).

The general metal contents at the sampled localities are indicated by the range, median and average (arithmetic mean) values of the chip samples (Table 1). It is characteristic that areas dominated by altered syenite (localities 2-5) are enriched in tantalum and show a lower $\mathrm{Nb}$ /Ta ratio than areas dominated by peralkaline microsyenite (locality 1 ).

Factor analysis. In a factor analysis of the analytical results for chip samples classified as altered syenite, four factors explain $78 \%$ of the total variation after varimax rotation. The correlations between the factors and the individual elements are illustrated in Table 2 . It appears that factor 1 is highly correlated with La-Ce$\mathrm{Y}$-Zr. These elements may occur in zircon rich in bastnaesite inclusions, or in eudialyte. The U-Ta-Nb association of factor 2 is readily explained by the existence of pyrochlore. In factor 3 the association $\mathrm{Sn}-\mathrm{Be}$, probably 
Table 1. Summary of metal contents in chip samples. Range and median/average in ppm

\begin{tabular}{|c|c|c|c|c|c|}
\hline & Loc. 1 & Loc. 2 & Loc. 3 & Loc. 4 & Loc. 5 \\
\hline Samples & 329 & 119 & 286 & 145 & 49 \\
\hline \multirow[t]{2}{*}{$\mathrm{Nb}$} & $10-8030$ & $20-4290$ & $120-7520$ & $240-11500$ & $310-6390$ \\
\hline & $260 / 820$ & $900 / 1070$ & $1600 / 1757$ & $1100 / 1638$ & $1170 / 1666$ \\
\hline \multirow[t]{2}{*}{ Ta } & $<1-378$ & $1-385$ & $8-693$ & $8-1110$ & $16-748$ \\
\hline & $9 / 38$ & $66 / 83$ & $138 / 161$ & $101 / 156$ & $141 / 189$ \\
\hline \multirow[t]{2}{*}{$\mathrm{Nb} / \mathrm{Ta}$} & $6-75$ & $2-54$ & $5-25$ & 6-162 & $7-19$ \\
\hline & $21 / 24$ & $13 / 14$ & $11 / 12$ & $12 / 14$ & N9/10 \\
\hline \multirow[t]{2}{*}{$\mathbf{U}$} & $<1-656$ & $2-254$ & $5-544$ & $9-723$ & $10-376$ \\
\hline & $15 / 46$ & $32 / 46$ & $64 / 79$ & $45 / 77$ & $65 / 96$ \\
\hline \multirow[t]{2}{*}{ Th } & $1-1960$ & $1-1070$ & $8-310$ & $19-1110$ & $19-228$ \\
\hline & $46 / 102$ & $53 / 69$ & $65 / 74$ & $97 / 118$ & $76 / 81$ \\
\hline \multirow[t]{2}{*}{$\mathrm{U} / \mathrm{Th}$} & $<0.1-10.6$ & $<0.1-5.3$ & $0.1-6.5$ & $<0.1-7.1$ & $0.2-4.1$ \\
\hline & $0.4 / 0.7$ & $0.7 / 1.1$ & $1.0 / 1.3$ & $0.5 / 0.8$ & $1.0 / 1.3$ \\
\hline \multirow[t]{2}{*}{$\mathrm{Zr}$} & $20-49684$ & $144-19062$ & $286-17241$ & $71-36433$ & $407-1027$ \\
\hline & $1106 / 4532$ & $2693 / 4050$ & $3160 / 4684$ & $4056 / 5489$ & $2033 / 2735$ \\
\hline \multirow[t]{2}{*}{$\mathrm{Ce}$} & $1-7870$ & $52-4260$ & $176-4330$ & $219-4570$ & $137-2730$ \\
\hline & $367 / 831$ & $773 / 968$ & $933 / 1131$ & $847 / 1089$ & $934 / 1022$ \\
\hline \multirow[t]{2}{*}{ La } & $1->2000$ & $32->2000$ & $88->2000$ & $117->2000$ & $75-1350$ \\
\hline & $218 / 466$ & $456 / 565$ & $529 / 622$ & $476 / 612$ & $467 / 529$ \\
\hline \multirow[t]{2}{*}{$\mathbf{Y}$} & $14-1245$ & $28-982$ & 28-1274 & $53-1206$ & $50-424$ \\
\hline & $76 / 164$ & $180 / 240$ & $204 / 292$ & $200 / 280$ & $136 / 155$ \\
\hline \multirow[t]{2}{*}{$\mathrm{Be}$} & $1-797$ & $1-102$ & $2-95$ & $7-287$ & $5-45$ \\
\hline & $13 / 26$ & $11 / 15$ & $18 / 20$ & $27 / 33$ & $13 / 15$ \\
\hline \multirow[t]{2}{*}{$\mathrm{Li}$} & $1-1810$ & $1-402$ & $<1-236$ & $<1-57$ & $<1-132$ \\
\hline & $42 / 86$ & $35 / 53$ & $31 / 41$ & $4 / 13$ & $11 / 22$ \\
\hline \multirow[t]{2}{*}{ Sn } & $<1-678$ & $1-472$ & $6-372$ & -195 & $4-51$ \\
\hline & $26 / 69$ & $24 / 45$ & $41 / 49$ & $47 / 51$ & $15 / 17$ \\
\hline \multirow[t]{2}{*}{ Mo } & $<1-202$ & $1-84$ & $<1-60$ & $<1-142$ & 3-39 \\
\hline & $4 / 8$ & $10 / 13$ & $5 / 6$ & $5 / 8$ & $10 / 12$ \\
\hline
\end{tabular}

hosted in mica, is negatively correlated with Mo, and factor 4 displays a negative correlation between $T h$ and Li.

Similar factor analyses have been performed for all chip samples from each of the investigated localities.
The results are summarized in Table 3, which shows the elements distinctly correlated with each factor. For locality 1 the separating of elements is minimal, but for the other localities the pattern from Table 2 can be recognized. Again the grouping of U-Nb-Ta is explained 
Table 2. Varimax rotated factor loadings for 527 chip samples classified as altered syenite

\begin{tabular}{lrrrrr}
\hline & Factor 1 & Factor 2 & Factor 3 & Factor 4 & \\
\hline $\mathrm{La}$ & 0.93 & 0.23 & 0.04 & 0.11 & $\mathrm{La}$ \\
$\mathrm{Ce}$ & 0.92 & 0.26 & 0.02 & 0.12 & $\mathrm{Ce}$ \\
$\mathrm{Y}$ & 0.92 & 0.05 & 0.21 & 0.04 & $\mathrm{Y}$ \\
$\mathrm{Zr}$ & 0.81 & 0.08 & 0.32 & 0.08 & $\mathrm{Zr}$ \\
$\mathrm{U}$ & -0.06 & 0.95 & 0.03 & 0.09 & $\mathrm{U}$ \\
$\mathrm{Nb}$ & 0.30 & 0.91 & 0.12 & -0.01 & $\mathrm{Nb}$ \\
$\mathrm{Ta}$ & 0.31 & 0.89 & -0.02 & -0.04 & $\mathrm{Ta}$ \\
$\mathrm{Sn}$ & 0.37 & 0.05 & 0.70 & 0.04 & $\mathrm{Sn}$ \\
$\mathrm{Be}$ & 0.15 & 0.03 & 0.61 & 0.46 & $\mathrm{Be}$ \\
$\mathrm{Mo}$ & -0.01 & -0.03 & -0.79 & 0.07 & $\mathrm{Mo}$ \\
$\mathrm{Th}$ & 0.39 & 0.21 & 0.14 & 0.70 & $\mathrm{Th}$ \\
$\mathrm{Li}$ & 0.04 & 0.08 & 0.03 & -0.75 & $\mathrm{Li}$ \\
\hline
\end{tabular}

by the occurrence of pyrochlore, whereas the La-Ce$\mathrm{Y}-\mathrm{Zr}$ might be due to zircon or eudialyte. The negative correlation of the pair Sn-Be with Mo is also repeated. It might be due to a large-scale zonation of these elements. The Ce-La-Th association of locality 5 indicates the existence of independent REE minerals as bastnaesite or monazite.

Interpolated geochemical maps. The topographic bases for the geochemical maps are digital terrain models (DTM) with $50 \times 50 \mathrm{~m}$ grids prepared by GGU in a previous project (Tukiainen \& Carlé, 1984). The maps were produced by two-dimensional panel kriging (Journel \& Huijbregts, 1978) in a surface approximating plane (SAP) and subsequent projection to the $x-y$ plane of the DTM. The kriging was performed in $25 \times 25 \mathrm{~m}$ grids in the SAP. The range of influence was used as search radius, but only the three samples nearest to each kriging point were used in the calculations.

Interpolated maps for niobium, tantalum, $\mathrm{Nb} / \mathrm{Ta}$ ratios, uranium and thorium were prepared (Thomassen, 1988). An example is shown in fig. 2a. Subsequently, area sizes and average metal contents were calculated in the DTM and SAP respectively for localities $1-4$ (Table 4). The table also shows figures calculated for three cases of tantalum and niobium cut-off values, and estimates of potential tonnages of the mineralisation.

Extrapolated geochemical maps. The correlations between airborne radiometric and geochemical data were established by regression analysis of chip sample values and gamma-spectrometric values. On this basis contour maps of niobium, tantalum and uranium were prepared by extrapolation in the $x-y$ plane (Thomassen, 1988). An example is shown in fig. $2 \mathbf{b}$.

In general the extrapolated geochemical maps agree well with the interpolated geochemical maps on the location of anomalous areas, but the metal values on the extrapolated maps are so different from the interpolated ones that they are not usable for cut-off estimations.

\section{Reconnaissance programme}

Alluvial samples. The local streams and alluvial plains were sampled by reconnaissance. The sample material comprises 29 heavy mineral concentrates produced by panning of the $<1 \mathrm{~mm}$ fraction of 15-20 kg stream sediment samples, and 4 raw sand samples of the same size. The samples were analysed for the usual 12 elements and also for $\mathrm{Cu}, \mathrm{Pb}, \mathrm{Ag}, \mathrm{Au}, \mathrm{W}, \mathrm{Ti}$ and $\mathrm{Fe}$.

Table 3. Summary of results for factor analysis of individual localities

\begin{tabular}{|c|c|c|c|c|c|}
\hline & Loc. 1 & Loc. 2 & Loc. 3 & Loc. 4 & Loc. 5 \\
\hline $\mathrm{F} 1$ & $\begin{array}{c}\text { Ta-Nb-Ce-U-La- } \\
\text { Zr-Y-Sn-Th }\end{array}$ & $\begin{array}{l}\text { La-Ce-Y- } \\
\text { (Th-Zr) }\end{array}$ & $\begin{array}{c}\text { Y-La-Ce-Zr- } \\
\text { (Th) }\end{array}$ & Y-Ce-La-Zr & $\begin{array}{l}\text { La-Ce-Th- } \\
\text { (Y-Sn) }\end{array}$ \\
\hline F2 & Li-Mo-Be & U-Nb-Ta & U-Nb-Ta & U-Nb-Ta & $\mathrm{Nb}-\mathrm{Ta}-\mathrm{U}$ \\
\hline F3 & & $\mathrm{Sn}-\mathrm{Be}$ & $\mathrm{Mo} /-\mathrm{Sn}$ & Be-Th-Sn & $\mathrm{Zr}-\mathrm{Y}$ \\
\hline F4 & & $\mathbf{L i}$ & $\mathrm{Li}-\mathrm{Be}$ & Mo-Li & $\mathrm{Be} /-\mathrm{Mo}$ \\
\hline F5 & & Mo & & & $\mathbf{L i}$ \\
\hline
\end{tabular}

Only elements with varimax rotated factor loadings $>0.5$ or $<-0.5$ are shown. 
Table 4. Metal contents of localities 1 to 4

\begin{tabular}{|c|c|c|c|c|}
\hline & Loc. 1 & Loc. 2 & Loc. 3 & Loc. 4 \\
\hline Total area $\left(\mathrm{m}^{2}\right)$ & 609631 & 630442 & 344650 & $175 \$ 49$ \\
\hline Nb-Ta-U-Th ppm & $551-29-29-53$ & $922-67-38-52$ & $1475-130-63-66$ & $1324-110-54-101$ \\
\hline $\begin{array}{l}\text { Potential tonnage } \\
\text { (million ton) }\end{array}$ & 150 & 300 & 100 & 500 \\
\hline \multicolumn{5}{|l|}{$>3500 \mathrm{ppm} \mathrm{Nb}$} \\
\hline Area $\left(\mathrm{m}^{2}\right)$ & 956 & 0 & 3067 & 3143 \\
\hline Nb-Ta-U-Th ppm & $4684-168-276-213$ & & $3835-312-105-79$ & $3780-252-116-113$ \\
\hline $\begin{array}{l}\text { Potential tonnage } \\
\text { (million ton) }\end{array}$ & 0.3 & 0 & 1 & 9 \\
\hline \multicolumn{5}{|l|}{$>250 \mathrm{ppm} \mathrm{Ta}$} \\
\hline Area $\left(\mathrm{m}^{2}\right)$ & 0 & 0 & 12046 & 11950 \\
\hline Nb-Ta-U-Th ppm & & & $2892-302-107-75$ & $2677-295-120-102$ \\
\hline $\begin{array}{l}\text { Potential tonnage } \\
\text { (million ton) }\end{array}$ & 0 & 0 & 4 & 34 \\
\hline \multicolumn{5}{|l|}{$>350 \mathrm{ppm} \mathrm{Ta}$} \\
\hline Area $\left(m^{2}\right)$ & 0 & 0 & 922 & 1261 \\
\hline Nb-Ta-U-Th ppm & & & 2948-353-73-90 & $3770-426-181-123$ \\
\hline $\begin{array}{l}\text { Potential tonnage } \\
\text { (million ton) }\end{array}$ & 0 & 0 & 0.3 & 4 \\
\hline
\end{tabular}

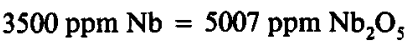

$250 \mathrm{ppm} \mathrm{Ta}=305 \mathrm{ppm} \mathrm{Ta}_{2} \mathrm{O}_{5}$

$350 \mathrm{ppm} \mathrm{Ta}=427 \mathrm{ppm} \mathrm{Ta}_{2} \mathrm{O}_{5}$

The values are calculated for total sampled areas and for three cut-off cases. Areas are from digital terrain models, and average metal contents are calculated by kriging in the surface approximating planes.

Not surprisingly the concentrates originating from the Motzfeldt Centre are enriched in most elements compared to samples derived from the basement. Only Fe, $\mathrm{Ti}, \mathrm{Cu}$ and $\mathrm{W}$ are enriched in the latter. The maximum values for the target elements are $3390 \mathrm{ppm} \mathrm{Nb}, 466$ ppm Ta, $318 \mathrm{ppm} \mathrm{U}$ and $1600 \mathrm{ppm}$ Th. Gold is only above the detection limit of $5 \mathrm{ppb}$ in four samples (max. $45 \mathrm{ppb}$ ), whereas relatively much tungsten (330 and 225 ppm) appears in two samples. Sand samples collected south of Motzfeldt $S \varnothing$ show no significant metal enrichment, whereas a sand sample from the NE coast is enriched in most elements (e.g. $540 \mathrm{ppm} \mathrm{Nb}, 40 \mathrm{ppm}$ Ta, 19 ppm U, 64 ppm Th, 3100 ppm Zr).

Sulphide mineralisation. The fault-associated sulphide mineralisation was cursorily sampled, mainly to test for gold. Two sampled vein zones are several tenths of metres wide, brecciated, strongly altered and invaded by quartz-fluorite stringers of centi- to decimetre thickness. The sulphides occur finely disseminated, as centimetre-large blebs and in semi-massive lenses, but the general sulphide content rarely exceeds a few per cent.
Pyrite is dominant, with trace amounts of chalcopyrite, sphalerite, galena and molybdenite.

Analyses of chip samples from outcrops show only slightly raised base/precious metal values. The best grab sample yielded $1 \% \mathrm{Cu}$ and $75 \mathrm{ppb} \mathrm{Au}$. The mineralisation therefore seems to be of marginal economic interest.

\section{Evaluation of results}

The conceptual model for the tantalum-enriched pyrochlore mineralisation at Motzfeldt $S \varnothing$ proposed by Tukiainen (1986) states that mineralisation occurs in a belt characterized by late-magmatic alteration along the outer margin of an alkaline intrusion. On the whole this model has been confirmed by the present study.

The systematic geochemical and geophysical data acquired during the Motzfeldt 87 Project have delineated the mineralised zone and have quantified the metal contents in selected parts of this zone, thereby making possible realistic estimates of the tonnage-grade potential. 
The radiometric and geochemical maps from the five investigated localities reveal that the mineralised zone is $200-300 \mathrm{~m}$ wide. It is orientated parallel with the intrusive contact at a distance of $200-400 \mathrm{~m}$, but this picture might be obscured by faulting. The combined length from locality 1 to locality 5 is at least $8 \mathrm{~km}$, and the vertical extension may exceed $500 \mathrm{~m}$. The zone is hosted by altered syenite or peralkaline microsyenite of the Motzfeldt Sø Formation.

Inside the zone, high and low $\mathrm{Nb}-\mathrm{Ta}-\mathrm{U}$ values are inhomogeneously distributed, i.e. the pyrochlore does not occur evenly disseminated throughout the zone. The high and low values tend to form alternating, parallel, c. $50 \mathrm{~m}$ wide belts. At localities 3 and 4 , two sets of near perpendicular belts of this type can be distinguished. Such a pattern could be explained as a control by late- to post-magmatic joint systems on the mineralising fluids. The geochemical maps of $\mathrm{Nb} / \mathrm{Ta}$ ratios reveal distinct vertical zonations of the two metals, with highest tantalum contents at the lowest level. This zonation is most obvious in the near vertical cliff at locality 3 where a $500 \mathrm{~m}$ vertical section through the mineralised zone was sampled.

The extrapolated geochemical maps indicate that the most promising parts of the mineralised zone were covered by the sampling at localities 1-3, whereas important anomalies remain unsampled at localities 4-5. The estimates of tonnage potentials presented in Table 4 are based on data from the sampled areas, the radiometric anomaly maps, and geological modelling. It appears that the mineralised zone has a potential of $c .600 \times 10^{6}$ tons of rock with average contents of $1320-1480 \mathrm{ppm}$ $\mathrm{Nb}, 110-130 \mathrm{ppm} \mathrm{Ta}, 50-60 \mathrm{ppm} U$ and $70-100 \mathrm{ppm}$ Th at the most promising of the investigated localities ( 3 and 4). Inside the mineralised zone smaller irregular areas with above average metal contents have been delineated. The most favourable of these areas occurs in locality 4 and contains $3770 \mathrm{ppm} \mathrm{Nb}, 426 \mathrm{ppm} \mathrm{Ta}, 181$ ppm $U$ and 123 ppm Th on average.

The largest potential for niobium-tantalum seems to exist at locality 4 , but the radiometric maps and the scant geochemical information from locality 5 imply a potential of comparable size at this locality. Consequently localities 4 and 5 are obvious targets for future investigations. Furthermore a possibility for placer formation exists. The $1.5 \times 3.0 \mathrm{~km}^{2}$ alluvial plain south of Motzfeldt $\mathrm{S} \varnothing$ holds the major potential for placer deposits.
Acknowledgements. The author thanks T. Tukiainen (geological and data analytical back up), K. Secher (project administration), J. Lau and $\mathbf{O}$. Plesner (logistical support from the base camp in Narsarsuaq), E. Dam and I. Rytved (field laboratory), L. Thorning (geophysical survey), L. Melchior Larsen and J. Pedersen (comments on this article) and finally the Swiss mountaineering team, the British geophysical staff and the IMSOR Image Processing Group for enjoyable co-operation.

\section{References}

Armour-Brown, A. Tukiainen, T. \& Wallin, B. 1980: The South Greenland regional exploration programme. Rapp. Grønlands geol. Unders. 100, 83-86.

Armour-Brown, A., Tukiainen, T., Wallin, B., Bradshaw, C. \& Emeleus, C. H. 1983: Uranium exploration in South Greenland. Rapp. Grønlands geol. Unders. 115, 68-75.

Briggs, I. C. 1974: Machine contouring using minimum curvature. Geophysics 39, 39-48.

Emeleus, C. H. \& Harry, W. T. 1970: The Igaliko nepheline syenite complex. General description. Bull. Grønlands geol. Unders. 85, $116 \mathrm{pp}$.

Journel, A. G. \& Huijbregts, C. J. 1978: Mining geostatistics, 600 pp. London: Academic Press.

Thomassen, B. 1987: The Motzfeldt 87 Project. Preliminary Report. Unpubl. intern. GGU rep., 83 pp.

Thomassen, B. 1988: The Motzfeldt 87 Project. Final Report. Grønlands geol. Unders. Open file Ser. 88/1, $81 \mathrm{pp.}$

Thomassen, B. \& Tukiainen, T. 1987: The Motzfeldt 87 Project. Field Report. Unpubl. intern. GGU rep., 16 pp.

Thomassen, B., Tukiainen, T. \& Secher, K. 1988: Detailed investigation of the niobium-tantalum distribution within the Motzfeldt Centre, South Greenland. Rapp. Grønlands geol. Unders. 140, 66-70.

Tukiainen, T. 1986: Pyrochlore in the Motzfeldt Centre of the Igaliko Nepheline Syenite Complex, South Greenland. Final Report. Unpubl. intern. GGU rep., 98 pp.

Tukiainen, T. 1988: Niobium-tantalum mineralisation in the Motzfeldt Centre of the Igaliko Nepheline Syenite Complex, South Greenland. In Boissonnas, J. \& Omenetto, P. (edit.) Mineral deposits within the European Community, 230-246. Berlin, Heidelberg: Springer-Verlag.

Tukiainen, T., Bradshaw, C. \& Emeleus, C. H. 1984: Geological and radiometric mapping of the Motzfeldt Centre of the Igaliko Complex, South Greenland. Rapp. Grønlands geol. Unders. 120, 78-83.

Tukiainen, T. \& Carlé, C. 1984: Aeroradiometri i 3D og farver. In Hansen, K. H., Christiansen, J. \& Carlé, C. (edit.) Tema grafik, 99-102. Copenhagen: RECAU/DAIMI.

B. $T$.,

Grønlands Geologiske Undersøgelse $\emptyset$ ster Voldgade 10, DK-1350 København K, Danmark. 